\title{
PERBANDINGAN PENGGUNAAN BAHAN BAKAR DAN NILAI TAMBAH INDUSTRI TEMPE PENGGUNA KAYU BAKAR
}

\author{
Enny Insusanty, Azwin, Emy Sadjati \\ Staf Pengajar Fakultas Kehutanan Universitas Lancang Kuning, \\ Jln. Yos Sudarso Km.8 Rumbai, Pekanbaru, Riau, Telp/Fax (0761) 54092
}

\begin{abstract}
This study aims to determine the use of various fuels and value -added soybean industry users of firewood. Experimental research method is to determine the time and the volume of a variety of fuels. To obtain data on value -added soybean industry firewood users do method survey conducted to tempe entrepreneurs with purposive sampling method.Based on data from the fuel use of the most efficient cooking time to enter into the boiling water experiment is the same volume that is 2 liters of data is obtained using the gas. LPG has a high thermal energy by combustion fuel for 7 minutes with a volume of $0.054 \mathrm{~kg}$ of fuel chart. Then followed with the use of kerosene to take 10 minutes and liters of fuel for boiling water 0,01. Fire resulting from green kerosene a little sooty issued. Meanwhile, firewood and wood pellets takes 15 minutes with a volume of $2 \mathrm{~kg}$ of fuel. Value of the average profit businesses tempeh is $\mathrm{Rp}$ 290,000 per sack (50 kg), which according to tempe entrepreneurs already minimal profit because of the high price of soybeans is currently through the price of Rp 450,000 / sack. With the price of Rp 9.000/kg obtained soybean processing industry added value of $R p 9000 / \mathrm{kg}$ soybean tempeh, profit Rp7.500/kg soybean, margin Rp $11.000 / \mathrm{kg}$ soybeans, and other inputs Rp 2000/kg ( $18.18 \%$ ) were include wood fuel input of Rp 500/kg soybean or $4.5 \%$
\end{abstract}

Key word: fuel, tempeh, add-value, firewood

\section{PENDAHULUAN}

Penggunaan energi fosil terus meningkat seiring dengan pertumbuhan penduduk dan pemenuhan kegiatan produktif untuk konsumsi. Harga bahan bakar fosil juga turut meningkat di pasaran ditambah lagi dengan kebijakan pemerintah untuk mengurangi subsidi BBM. Penggunaan migas dan batubara menyumbang sekitar 80\% kebutuhan energi dunia dan menghasilkan banyak sekali emisi karbon dan gas rumah kaca lainnya ( Dwiprabowo, H dkk 2012).

Krisis energi dunia yang terjadi pada dekade terakhir yang terus terjadi memberi dampak yang signifikan pada meningkatnya harga bahan bakar fosil, sehingga telah mendorong pengembangan energi alternatif dengan 
pemanfaatan sumberdaya energi terbarukan (renewable resources). Dengan jumlah penduduk Indonesia 237.641.326 jiwa menurut sensus kependudukan 2010 yang diliris oleh BPS (2012) dan akan terus meningkat sebesar 1,49 \% per tahun, maka pemanfaatan energi perkapita akan ikut meningkat. Jumlah penduduk yang besar membuat pemerintah harus menemukan sumber-sumber energi alternatif untuk memenuhi kebutuhan energi. Salah satu bentuk energi alternatif yang saat ini mulai dikembangkan adalah Bahan Bakar Biomassa (BBB) yang rendah emisi. Pengembangkan energi alternatif BBB diperlukan untuk mendukung kegiatan produktif yang telah ada serta sebagai upaya untuk mengembangkan kegiatan produktif yang baru untuk meningkatkan nilai tambah bagi perekonomian daerah.

Pemanfaatan energi biomassa yang bersumber dari kayu banyak dilakukan oleh industri kecil dan rumah tangga. Industri kecil umumnya keterbatasan teknologi dan modal namun memiliki keluwesan dalam penggunaan sumber energi karena kebutuhan energinya dapat diperoleh dari BBG dan BBB yang berasal dari limbah sektor pertanian, perkebunan dan kehutanan. Bentuk BBB cukup beragam seperti serbuk gergaji, sabetan, kayu bakar.

Nilai ekonomi dari usaha kecil dan rumah tangga untuk menghasilkan nilai tambah dan menjadi unit usaha yang dapat menjadi lapangan kerja bagi masyarakat. Usaha kecil dan rumah tangga seperti usaha tempe yang banyak diusahakan menggunakan energi kayu bakar sebagai sumber energi. Kayu bakar diperoleh dari berbagai tempat dengan cara membeli ataupun mencari sendiri untuk mengurangi ongkos produksi. Pemanfaatan kayu bakar sebagai sumber energi menjadi pilihan utama karena lebih murah dan praktis serta masih relatif mudah untuk diperoleh. Kebutuhan energi dari kayu bakar dapat juga disubsitusi dengan sumber energi yang lain seperti pellet kayu, serbuk kayu, gas maupun minyak tanah. Hal ini dapat terjadi jika terjadi kelangkaan terhadap bahan bakar kayu. Akan tetapi hal ini dapat menambah biaya produksi dari usaha kecil tersebut.

Pemanfaatan energi alternatif yang rendah emisi, efisien, dan murah semakin digalakkan perlu diketahui perbandingan ekonomi dari BBB. Penggunaan BBB yang efisien diharapkan dapat mengurangi 
penggunaan energi yang berasal dari fosil dan memperoleh tanpa mengurangi keuntungan dari masyarakat. Penggunaan Bahan bakar biomassa (BBB) khususnya dari limbah kayu merupakan salah satu bentuk energi alternatif sebagai merupakan pilihan utama yang digunakan oleh industri kecil dan rumah tangga untuk menekan biaya produksi sekaligus meningkatkan nilai tambah industri tempe .

Selain itu saat ini juga telah diupayakan berbagai bentuk energi alternatif, diantaranya berasal dari limbah kayu yaitu wood pellet. Wood pellet adalah partikel kayu yang dipadatkan yang digunakan sebagai bahan bakar (Jones, et. al., 2012). Pellet merupakan hasil pengempaan biomassa yang memiliki tekanan yang lebih besar dibandingkan briket (Hendra, 2012). Wood Pellet sudah banyak digunakan di beberapa daerah di suatu Negara dengan tujuan ekspor, di beberapa tempat semakin popular seiring dengan mahalnya sumber energi primer serta tuntutan terhadap mitigasi perubahan iklim (Jones, et. al., 2012).

Tujuan dari penelitian ini adalah (1) menghitung efisiensi waktu dan volume penggunaan berbagai bentuk bahan bakar yaitu kayu bakar, gas, minyak tanah dan wood pellet menghitung nilai tambah industri kecil dan rumah tangga pengguna kayu bakar yaitu usaha tempe

\section{METODE PENELITIAN Waktu dan Lokasi Penelitian}

Penelitian ini dilakukan selama 8 bulan mulai bulan Oktober 2013 sampai dengan Mei 2014 dengan mengambil lokasi Rumbai Kota Pekanbaru.

\section{Bahan dan Peralatan Penelitian}

Peralatan penelitian yang digunakan adalah timbangan gantung untuk mengukur berat bahan bakar kayu kuisioner dan panduan wawancara, penghitung waktu (timer), gelas ukur, alat perekam data dan gambar, tally sheet untuk pencatatan lapangan, alat tulis dan perangkat komputer

\section{Pengumpulan data}

Data yang diperlukan dalam penelitian ini adalah data primer dan data sekunder yang dikumpulkan dari berbagai sumber data.

a. Pengumpulan Data Sekunder

Pengumpulan data dilakukan dengan penelusuran pustaka. Data sekunder dikumpulkan dari berbagai sumber yang relevan dalam rentang waktu tertentu. Data skunder yang diperlukan antara lain, BPS Kota Pekanbaru dan Dinas Perindustrian.

b. Pengumpulan Data Primer 
Data primer diperoleh melalui kegiatan survey lapangan dengan pengambilan responden secara purposive sampling terhadap pengguna energi pada industri kecil dan rumah tangga makanan dalam hal ini pembuatan tempe. Untuk mengetahui perbandingan bahan bakar dilakukan uji coba terhadap penggunaan bahan bakar yang berbeda seperti kayu bakar, gas, minyak tanah, dan pellet kayu.

\section{Pengolahan dan Analisis data}

Untuk

membandingkan penggunaan minyak tanah, BBG (bahan bakar gas), BBB (bahan bakar biomassa/ kayu bakar) dan wood pellet dilakukan dengan membuat perbandingan waktu memasak, jumlah bahan bakar dan volume output.

Konsep nilai tambah menurut Hayami dalam Hidayat T.R (2009) dan Sinaga M.S (2008) adalah pertambahan nilai suatu komoditi karena adanya input fungsional yang diberlakukan pada komoditi tersebut. Input fungsional tersebut berupa proses mengubah bentuk (form utility), memindahkan tempat (place utility) dan menyimpan (time utility). Terdapat beberapa variabel penting dalan analisis nilai tambah metode Hayami yaitu, faktor konversi yang menunjuk pada banyaknya output yang dihasilkan dari satu satuan input; factor koefisien tenaga kerja yang menunjukkan pada banyaknya tenaga kerja langsung yang diperlukan untuk mengolah satu-satuan input; dan nilai produk yang menunjukkan pada nilai output yang dihasilkan dari satu-satuan input. Dengan perkataan lain analisis nilai tambah metode Hayami menggambarkan imbalan bagi tenaga kerja, modal dan manajemen.

\section{HASIL DAN PEMBAHASAN Penggunaan Bahan Bakar}

Penggunaan bahan bakar yang dapat dilakukan dengan ragam yang ada di masyarakat cukup beragam. Bakan bakar yang tradisional adalah berasal dari kayu bakar yang banyak dimanfaatkan oleh rumah tangga pedesaan. Untuk masyarakat perkotaan telah banyak beralih ke bahan bakar gas dan minyak tanah karena keterbatasan ketersediaan kayu bakar dan kondisi perkotaan yang padat.

Kayu bakar merupakan sumber energi penting untuk memasak baik untuk rumah tangga maupun industri rumah tangga di wilayah pedesaan. Hasil studi RWEDP menunjukkan bahwa pertumbuhan ekonomi di kawasan Asia Tenggara tidak menurunkan konsumsi 
kayu bakar penduduk bahkan cenderung meningkatkan. Meskipun kebijakan konversi gas telah menyentuh wilayah pedesaan namun kenyataan menunjukkan penggunaan kayu bakar tetap tinggi (Dwiprabowo, 2010).

Selain di pedesaan penggunaan kayu bakar banyak digunakan oleh industri rumah tangga sebagai sumber energi yang membutuhkan kegiatan pembakaran seperti usaha tahu tempe, makanan (rumah makan), kopi, pembuatan mie sagu, sate, ikan salai dan sebagainya. Alasan penggunaan kayu bakar dinilai lebih hemat secara ekonomi dan memberikan rasa yang lebih baik bagi makanan.

Jenis kayu bakar yang disukai pada umumnya kayu keras karena lebih banyak menghasilkan kalori seperti jenis akasia, karet, mahoni, mahang, meranti dan kayu buah-buahan. Penggergajian kayu yang banyak terdapat di Pekanbaru menghasilkan limbah dapat menjadi sumber kayu bakar

Kayu bakar yang diolah menjadi bentuk lain yang lebih efisien adalah membuat menjadi pellet kayu (wood pellet). Pelet kayu juga merupakan bahan bakar yang ramah lingkungan, bahan bakar $\mathrm{CO}_{2}$ netral, terbuat dari limbah kayu (serbuk gergajian atau cacahan kayu), dikompres dengan tekanan tinggi tanpa menggunakan perekat atau zat aditif tambahan. Bentuknya silinder dengan diameter 6-10 $\mathrm{mm}$ dan panjang $10-30 \mathrm{~mm}$. Sebagai bahan bakar berstandar tingggi dan kepadatan tinggi, pellet memiliki biaya transportasi yang efisien dan pengoperatian otomatis untuk pemanas dan energi dari rumah pribadi hingga ke skala instalasi energy yang besar. Pohon yang bisa digunakan sebagai bahan baku pelet kayu berasal dari jenis pohon cepat tumbuh seperti pinus, kaliandra, akasia, sengon, mahang dan lain-lain. Jika jenis kayu yang digunakan merupakan kayu rimba campuran dan meranti akan menghasilkan energi kalor yang lebih tinggi, namun dalam pembuatan wood pellet menggunakan mesin dengan dengan tenaga yang lebih tinggi.

Wood pellet merupakan salah satu dari kelompok energi biomassa. Pellet adalah bentukan utam dari limbah kayu, meliputi : serbuk gergaji, shavings, wood chips, yang dihasilkan dari pembagian batang, furniture dan hasil hutan lainnya. Proses pembuatan pellet kayu terdiri atas beberapa langkah : bahan baku, penyaringan (screening), penggerusan (grinding), pengeringan 
(drying), pembuatan butiran (pelletizing), pendinginan (cooling), penyaringan kembali (screening), dan pengapaka (packaging) (Roos and Brackley, 2012).

Minyak tanah juga merupakan bahan bakar yang banyak digunakan di sektor rumah tangga dan industri RT. Penggunaan minyak tanah telah bergeser kepada gas karena adanya kebijakan pemerintah tentang konversi minyak tanah ke gas untuk mengurangi subsidi BBM yang berlangsung mulai tahun 2006 akibatnya minyak tanah mengalami kenaikan yang sangat signtifikan.

Dari aspek fisik, minyak tanah bersifat cair sehingga transportasi, pengemasan, dan penjualan sistem eceran pun mudah. Masyarakat kecil bisa membeli minyak tanah hanya 0.5 liter yang harganya sekitar Rp 1,500 per liter untuk minyak tanah bersubsidi dan mereka bisa membawanya dengan mudah. Namun tanpa subsidi harga minyak tanah akan melambung menjadi Rp 9.000/liter. Minyak tanah tersebut juga bisa dimasukkan ke dalam plastik. Hal ini jelas tak mungkin bisa dilakukan untuk pembelian elpiji, karena elpiji dijual per tabung, yang isinya tiga kilogram dengan harga sekitar $\mathrm{Rp}$ 18,000.
Masyarakat jelas tidak mungkin bisa membeli elpiji hanya 0.5 kilogram dan membawanya dengan plastik atau kaleng susu. Dari aspek kimiawi, elpiji jauh lebih mudah terbakar dibanding minyak tanah. Harga tabung gas juga relatif mahal yaitu Rp 150.000 untuk tabung $3 \mathrm{~kg}$ dengan harga kompor mencapai sekitar Rp 300.000,-.

Tahun 2007 hingga 2010 merupakan tahun dimana pemerintah gencar-gencarnya melakukan sosialisasi penggunanan gas Liquefied Petroleum Gas (LPG/elpiji) bagi konsumsi rumah tangga dan industri kecil sekaligus membagikan kompor gas beserta tabung gas elpiji yang berisi $3 \mathrm{~kg}$ secara gratis kepada masyarakat. Peraturan Presiden Republik Indonesia Nomor 104 tahun 2007 tentang Penyediaan, Pendistribusian, dan Penetapan Harga LPG Tabung 3 (tiga) kilogram dan Peraturan Menteri Energi dan Sumber Daya Mineral (ESDM) No. 21 Tahun 2007 tentang Penyelenggaraan Penyediaan dan Pendistribusian LPG Tabung $3 \mathrm{Kg}$, menjadi dasar hukum kebijakan tersebut. Dari segi efisiensi penggunaaan bahan bakar dapat dilihat pada tabel 1. 
Tabel 1 perbandingan bahan bakar

\begin{tabular}{|c|c|c|c|c|c|}
\hline No & Uraian & $\begin{array}{c}\text { Minyak tanah } \\
\text { /BBM } \\
\end{array}$ & Gas/ BBG & Kayu bakar & Wood pellet \\
\hline 1 & Volume air & 2 liter & 2 liter & 2 liter & 2 liter \\
\hline 2 & Jumlah bahan bakar & 0.01 liter & $0.054 \mathrm{~kg}^{*}$ & $2 \mathrm{~kg}$ & $2 \mathrm{~kg}$ \\
\hline 3 & Waktu memasak & 10 menit & 7 menit & 15 menit & 15 enit \\
\hline
\end{tabular}

Berdasarkan data penggunaan bahan bakar dapat dilihat waktu memasak yang paling efisien degan melakuan percobaaan terhadap perebuasan air dengan volume yang sama yaitu 2 liter diperolah data adalah menggunakan gas. Gas elpiji memiliki energi panas yang tinggi dengan pembakaran yang lebih sempurna yaitu 7 menit. Kemudian disusul dengan penggunaan minyak tanah dengang memakan waktu 10 menit untuk perebusan air. Nilai kalor minyak tanah 11.100 (kKal $/ \mathrm{kg}$ ) (Anonim 2013). Api yang dihasilkan dari minyak tanah berwarna hijau dengan sedikit mengeluarkan jelanga. Berdasarkan penelitian yang dilakukan oleh Laboratorium Energi Universitas Trisakti menghasilkan biaya merebus air 5 liter adalah Rp 11,6/menit untuk LPG dan Rp 13,8/menit untuk Minyak Tanah (ESDM, 2013)

Untuk kayu bakar penggunaan kayu menghabiskan waktu $2 \mathrm{~kg}$ dengan waktu 15 menit sama dengan wood pellet hal ini terkait dengan penggunaan bara pada kayu. Wood pellet yang digunakan pada penelitian ini berasal dari kayu mahang yang dibuat dengan cara basah yaitu dengan mencampur tepung tapioka dan sedikit air dan kemudian dicetak menggunakan mesin. Wood pellet yang dibuat dengan cara basah menyebabkan asap yang lebih banyak. Sedangkan pada wood pellet dengan cara kering tanpa tambahan tepung tapioca hanya dan lebih sedikit air dengan mesin yang lebih tinggi kapasitasnya.

Penggunaan wood pellet hampir sama dengan kayu bakar dengan meghasilkan jelanga dan asap. Cara menghidupkan juga tidak jauh berbeda dengan kayu bakar dengan membuat penyalaan api dengan bantuan minyak tanah ataupun plastik sehingga dapat menghasilkan nyala api. Kompor untuk wood pellet juga dirancang khusus yang dapat digunakan secara praktis dan ditambah dengan blower (kipas) yang dihubungkan dengan listrik berdaya kecil. Kompor tanpa blower juga tersedia 
namun api yang dihasilkan kurang optimal.

Untuk Nilai ekonomis dari penggunaan bahan bakar adalah sebagai berikut:

1. Pengeluaran minyak tanah setiap rumah tangga membutuhkan 1 liter minyak perhari Dengan harga 9000 sehingga dibutuhkan biaya $R p$ 270.000/bulan

2. Kebutuhan gas selama 1 bulan adalah $12 \mathrm{~kg}$ gas dengan harga $\mathrm{Rp}$ 110. 000 jika menggunakan tabung gas $12 \mathrm{~kg}$ atau tanpa subisidi. Untuk penggunaan gas subsidi dibutuhkan 4 tabung dengan harga konsumen $\mathrm{Rp}$ 18.000 maka biaya untuk komsumsi gas perbulan adalah hanya Rp72.000

Penghematan yang diperoleh dari penggunaan gas yaitu Rp 160.000 /bulan dengan menggunakan tabung gas $12 \mathrm{~kg}$ dan Rp 198.000 denga menggunakan tabung gas $3 \mathrm{~kg}$ (subsidi untuk tabung gas $3 \mathrm{~kg}$ lebih besar)

\section{Nilai ekonomi Kayu bakar pada Usaha Tempe}

Usaha kecil dan rumah tangga seperti pembuatan tempe sangat mengandalkan kebutuhan energinya pada kayu bakar. Hal ini disebabkan oleh nilai kalor yang dihasilkan cukup tinggi dan harga relatif murah. Bahkan sebagian pengusaha tempe rumah tangga di Rumbai mencari sendiri kayu bakar di sekitar Kota Pekanbaru seperti di Muara Fajar dengan alasan menghemat biaya produksi tempe. Sebagian lagi meperoleh bahan bakar dengan cara membeli pada penjual kayu bakar dengan harga Rp 250.000/ mobil ataupun berasal dari kayu penggergajian berupa sabetan.

\section{Tabel 2. Perhitungan Ekonomi Usaha Pembuatan Tempe}

\begin{tabular}{clr}
\hline No & \multicolumn{1}{c}{ Uraian } & Rata-rata \\
\hline 1 & Pengeluaran bahan baku Kedelai (Rp)/bulan & $9,030,000.00$ \\
\hline 2 & Volume kedelai (1 minggu) kg & 227.50 \\
\hline 3 & Volume kedelai/bulan (kg) & 910.00 \\
\hline 4 & Volume 1 kali masak (kg) & 37.50 \\
\hline 5 & Lamanya sekali Memasak (jam) & 2.30 \\
\hline 6 & Volume /berat bahan bakar (kg) & 30.00 \\
\hline 7 & Pengeluaran bahan bakar/bulan & $750,000.00$ \\
\hline 8 & Biaya tenaga kerja (1 orang)/bulan & $1,500,000.00$ \\
\hline 9 & Biaya lainnya & $1.100,000.00$ \\
\hline 10 & Total Pengeluaran & $12,650,000,00$ \\
\hline 11 & Nilai jual produk (Rp)/bulan & $70,720,000.00$ \\
\hline 12 & Nilai keuntungan/ minggu (Rp) & $1,395,500.00$ \\
\hline 13 & Keuntungan/bulan (Rp) & $5,582,000.00$ \\
\hline 15 & Keuntungan /50 kg & $290,500.00$ \\
\hline
\end{tabular}


Nilai keuntungan rata-rata usaha tempe adalah Rp 290.000 per karung (50 $\mathrm{kg}$ ), dimana menurut pengusaha tempe keuntungan ini sudah minimal karena tingginya harga kedelai yang saat ini menembus harga $\operatorname{Rp} 450.000$ /karung. Kedelai yang digunakan oleh pengusaha tempe merupakan kedelai impor, jika menggunakan kedelai lokal tempe yang dihasilkan kurang bagus. Sementara harga jual tempe ke konsumen sulit untuk bisa dinaikkan karena dapat mengurangi jumlah penjualan. Untuk analisis nilai tambah industri tempe dengan metode Hayami dapat dilihat pada tebel 3.

Tabel.3 Analisis Nilai Tambah Usaha Tempe

\begin{tabular}{|c|c|c|}
\hline No & VARIABEL & NILAI \\
\hline I & OUTPUT, INPUT DAN HARGA & \\
\hline 1. & Output $(\mathrm{kg} /)$ & 500 potong \\
\hline 2. & Input (kg/) & 50 \\
\hline 3 & Tenaga Kerja (HOK) & 1 \\
\hline 4 & Faktor Konversi & $(4)=(2) /(1)=10$ \\
\hline 5 & Koefisien Tenaga Kerja & $(5)=(3) /(2)=0.02 \mathrm{HOK} / \mathrm{kg}$ \\
\hline 6 & Harga Output (Rp/kg) & $(6)=2000 /$ potong \\
\hline 7 & $\begin{array}{l}\text { Upah rata-rata tenaga kerja langsung } \\
\text { (Rp/HOK) }\end{array}$ & $(7)=75.000$ \\
\hline II & PENDAPATAN DAN KEUNTUNGAN & \\
\hline 8 & Harga Bahan bahan baku (Rp/kg) & 9.000 \\
\hline 9 & Sumbangan Input Lain (Rp/kg) & 2.000 \\
\hline 10 & Nilai output $(\mathrm{Rp} / \mathrm{kg})$ & $(10)=(4 \times 6)=10 \times 2.000=20.000$ \\
\hline \multirow[t]{2}{*}{11} & a. Nilai tambah $(\mathrm{Rp} / \mathrm{kg})$ & $\begin{array}{c}(11 a)=(10)-(9)-(8)= \\
20.000-2.000-9.000=9000\end{array}$ \\
\hline & b. Rasio nilai tambah (\%) & $\begin{array}{c}(11 \mathrm{~b})=(11 \mathrm{a}) /(10) \times 100 \% \\
=9000 / 20.000 \times 100 \% \\
=0.45\end{array}$ \\
\hline \multirow[t]{2}{*}{12} & $\begin{array}{l}\text { a. Pendapatan tenaga kerja langsung } \\
(\mathrm{Rp} / \mathrm{kg})\end{array}$ & $(12 \mathrm{a})=(5) \times(7)=0.02 \times 75000=1.500 \mathrm{~kg}$ \\
\hline & b. Pangsa tenaga kerja (\%) & $\begin{aligned} & (12 \mathrm{~b})=(12 \mathrm{a}) /(11 \mathrm{a}) \times 100 \\
= & 1500 / 9000 \times 100=16.77 \%\end{aligned}$ \\
\hline \multirow[t]{2}{*}{13} & a. Keuntungan $(\mathrm{Rp} / \mathrm{Kg})$ & $\begin{array}{c}(13 a)=(11 a)-(12 a)=9000-1500 \\
=7500\end{array}$ \\
\hline & b. Tingkat keuntungan (\%) & $\begin{array}{c}(13 b)=(13 a) /(11 a) \times 100 \% \\
=7500 / 9000=83.33 \%\end{array}$ \\
\hline III & BALAS JASA FAKTOR PRODUKSI & \\
\hline 14 & Margin $(\mathrm{Rp} / \mathrm{kg})$ & $\begin{array}{c}(14)=(10)-(8) \\
=20000-9.000=11.000\end{array}$ \\
\hline & a. Pendapatan tenaga kerja (\%) & $\begin{aligned} & (14 \mathrm{a})=(12 \mathrm{a}) /(14) \times 100 \% \\
= & 1500 / 11.000 \times 100 \%=13.63 \%\end{aligned}$ \\
\hline & b. Sumbangan input lain (\%) & $\begin{array}{c}(14 b)=(9) /(14) \times 100 \% \\
=2000 / 11000 \times 100 \%=18.18 \%\end{array}$ \\
\hline & c. Keuntungan pemilik perusahaan (\%) & $\begin{aligned} & (14 \mathrm{c})=(13 \mathrm{a}) / 14 \times 100 \% \\
= & 7500 / 11.000 \times 100 \%=68.18 \%\end{aligned}$ \\
\hline
\end{tabular}


Berdasarkan Tabel 2 diketahui bahwa dengan harga kedelai $\mathrm{Rp}$ 9.000/kg diperoleh nilai tambah pengolahan industri tempe sebesar $R p$ 9000/kg kedelai, keuntungan sebesar Rp $7.500 / \mathrm{kg}$ kedelai, marjin sebesar $\mathrm{Rp}$ $11.000 / \mathrm{kg}$ kedelai, dan sumbangan input lain sebesar Rp 2000 (18.18\%) yang termasuk input bahan bakar kayu yaitu Rp 500/kg kedelai atau $4.5 \%$

\section{KESIMPULAN}

1. Perbandingan penggunaan bahan bakar untuk perebusan 2 liter air dengan minyak tanah memerlukan waktu 10 menit dan volume 0.01 liter, gas membutuhkan waktu 7 menit sedangkan penggunaan kayu bakar dan wood pellet memerlukan $2 \mathrm{~kg}$ bahan bakar dengan waktu selama 15 menit.

2. Dengan harga kedelai Rp 9.000/kg diperoleh nilai tambah pengolahan industri tempe sebesar Rp 9000/kg kedelai, keuntungan sebesar Rp $7.500 / \mathrm{kg}$ kedelai, marjin sebesar $\mathrm{Rp}$ $11.000 / \mathrm{kg}$ kedelai, dan sumbangan input lain sebesar $\mathrm{Rp}$ 2000,-/kg $18.18 \%$ yang termasuk input bakan bakar kayu yaitu Rp 500/kg kedelai atau $4.5 \%$

\section{DAFTAR PUSTAKA}

BPS, Indonesia dalam Angka 2012. Badan Pusat Statistik
Dwiprabowo, H. Irawanti, Sylviani, Suryandari dan Suka 2012 Kajian Ekonomi Aplikasi Teknologi Rendah Emisi, Pada Industri Kecil-Menengah. Laporan Akhir Insentif Peningkatan Kemampuan Peneliti Dan Perekayasa

Dwiprabowo. H. 2010. Kajian Kebijakan Kayu Bakar Sebagai Sumber Energi Di Pedesaan Pulau Jawa. Jurnal Analisis Kebijakan Kehutanan Vol. 7 No. 1, April 2010 : $1-11$

ESDM, 2013. Konversi Minyak Tanah ke LPG : Menggerakkan Perekonomian, Menghemat Energi http://esdm.go.id/berita/56artikel/4011-konversi-minyaktanah-ke-Ipgmenggerakkanmenghematenergi.html?tmpl= component\& print $=1$ 1 page $=$ diakses 3 Juni 2014

Hendra, D. 2012. Rekayasa Pembuatan Mesin Pelet Kayu dan Pengujian Hasilnya. Jurnal Penelitian Hasil Hutan Vol. 30 No. 2 Juni 2012. Pusat Penelitian dan Pengembangan Keteknikan Kehutanan dan Pengolahan Hasil Hutan. Bogor

Jones, D., D. Harper, and A. Taylor. 2012. Wood Pellets, an Introduction to Their Production and Use. Forest Prooduct Center, Mississipi State University. Mississipi

Sinaga M.S. 2008. Analisis Nilai Tambah dan Daya saing serta Dampak Kebijakan Pemerintah Terhadap Industri Tempe di Kabupaten Bogor. Kasus: Desa Citeurep, Kecamatan Citeureup. Program Studi Ekonomi Pertanian dan Sumberdaya, Fakultas Pertanian, Institut Pertanian Bogor. Bogor. pp. 95 hal 